\title{
FT-IR, Molecular Structure and Nonlinear Optical Properties of 2-(pyranoquinolin-4-yl)malononitrile (PQMN): A DFT Approach
}

\author{
Mohamed A. M. El-Mansy ${ }^{1,2}$, Medhat Ibrahim ${ }^{3, *(D)}$, Huda S. Soliman ${ }^{4}$, Sara M. Atef ${ }^{4}$ \\ 1 Molecular Modeling Simulation Lab., Department of Physics, Faculty of Education, Ain Shams University, Roxy, Cairo, \\ Egypt \\ 2 Condensed Matter Theory Group, Department of Physics, College of Science and Arts, Qassim University, Ar Rass, 51921, \\ Saudi Arabia \\ 3 Molecular Spectroscopy and Modeling Unit, Spectroscopy Department, National Research Centre, 33 El-Bohouth St., \\ 12622 Dokki, Giza, Egypt \\ 4 Thin Film Semiconductor Lab., Department of Physics, Faculty of Education, Ain Shams University, Roxy, Cairo, Egypt \\ * Correspondence: ma.khalek@nrc.sci.eg;
}

Received: 30.12.2020; Revised: 3.02.2021; Accepted: 8.02.2021; Published: 15.05.2021

\begin{abstract}
A combined experimental and theoretical study for Fourier transform infrared spectra for 2(pyranoquinolin-4-yl)malononitrile (PQMN) compound has been made. In advance, we investigate many physical characteristics based on DFT/B3LYP using 6-311G(d,p) basis set such as optimum structure, vibrational frequencies, thermo-chemistry, overall dipole moment, HOMO/LUMO Bandgap, nuclear repulsive energy and ionization energies, electronic affinity and chemical potential, global electrophilicity index, global hardness and finally softness $(\zeta)$. Also, we studied the non-linear optical (NLO) properties of PQMN. Results emphasize both degeneracy and diamagnetic properties of PQMN. PQMN Frontiers' molecular orbitals (FMOs) split into two distinguished alpha (spin $\uparrow$ ) and beta (spin $\downarrow$ ) states with the same energy $3.7 \mathrm{eV}$, although its singlet spins state. Moreover, the calculated dipole moment (DM) value (13.3 Debye) for PQMN explains the mystery behind its reactive tendency with the nearby media. PQMN is a unique model for a degenerate diamagnetic semiconductor that can be easily used for optoelectronic manufactured devices such as solar cells and spintronic devices.
\end{abstract}

Keywords: PQMN; degeneracy/diamagnetism; DFT/B3LYP; FT-IR; FMOs; DOS.

(C) 2021 by the authors. This article is an open-access article distributed under the terms and conditions of the Creative Commons Attribution (CC BY) license (https://creativecommons.org/licenses/by/4.0/).

\section{Introduction}

The major condensed nitrogen heterocyclic materials are extracted from natural plants or living tissues [1]. The most popular category of condensed nitrogen heterocyclic compounds is quinoline derivatives due to their biological activities that can be applied as antiviral, analgesic [2], antineoplastic, vasodilator, antiischemic, antiallergic, anticancer [3], antihypertensive, anti-ulcerative, anti-inflammatory, inhibitors of human Chk1 kinase, molluscicidal, anti-fungicidal [4], and also as biodegradable agrochemicals [5]. Furthermore, some of these quinolines are commonly in employment, such as cosmetics and pigments [6]. They are also used as antimicrobial agents preventing several infections spread involving respiratory, abdominal, and urinary tract infections [7]. We select 2-(pyranoquinolin-4-yl) malononitrile (PQMN) as a new derivative of the Quinoline family to be the interest of our study. Literature review reveals that no spectroscopic notes have been reported on PQMN compound so far. Such study will be of great interest to report spectroscopic molecular 
properties of PQMN using molecular modeling techniques [8]. Molecular modeling has become a powerful tool to investigate molecular and vibrational properties using quantum chemical computations. Density functional theory (DFT), especially Becke3-Lee-Yang-Parr (B3LYP) method, is the most accurate tool used for vibrational frequencies assignments as well as complex organic systems bonding and structural features [9-18]. Our present study aims to report spectroscopic notes on 2-(pyranoquinolin-4-yl)malononitrile (PQMN) compound. Also, we will investigate various molecular and vibrational characteristics such as optimum structure, vibrational frequencies, thermo-chemistry, overall dipole moment, HOMO/LUMO Bandgap, nuclear repulsive energy and ionization energies, electronic affinity and chemical potential, global electrophilicity index, global hardness, and finally softness ( $\zeta$ ) using DFT/B3LYP utilizing 6-311G(d,p) basis set.

\section{Materials and Methods}

\subsection{Synthesis of PQMN material.}

PQMN was prepared by adding 4-chloro-6-ethyl-3-nitropyrano[3,2-c]quinoline2,5(6H)-dione $(3.20 \mathrm{~g}, 10 \mathrm{mmol})$ and malononitrile $(0.70 \mathrm{~g}, 10 \mathrm{mmol})$ in a flask containing absolute ethanol $(50 \mathrm{~mL})$ with a few drops of triethylamine. Then the mixture was stirred for 2 h. After cooling, The deposited solid was filtered and crystallized from methanol to produce PQMN in the form of yellow crystals [19].

\subsection{FT-IR spectroscopic analyses.}

We compress a mixture of $50 \mathrm{mg}$ of vacuum-dried IR-grad $\mathrm{KBr}$ and $1 \mathrm{mg}$ of PQMN powder to applicable circular disk for performing FT-IR analysis in the spectral range of 500$4000 \mathrm{~cm}^{-1}$ at room temperature using Thermo Scientific Nicollet 460 plus spectrophotometer.

\subsection{Theory/calculation.}

Our quantum chemical computations were performed using Gaussian (09W) program package [20] in addition to GaussView 5 [21] used for visualization of the structure and simulation of the vibrational modes. Theoretical iterations are based upon DFT/B3LYP utilizing 6-311G(d,p) basis set on a PC Core I5/2.8 GHz. First, we calculate PQMN optimum structure as shown in Fig. 1, and then we calculate the vibrational frequencies. Also, we calculate many physical parameters such as thermo-chemistry, overall dipole moment, HOMO/LUMO Bandgap, nuclear repulsive energy and ionization energies, electronic affinity and chemical potential, global electrophilicity index, global hardness, and finally softness $(\zeta)$ at the same theory level.

\section{Results and Discussion}

\subsection{Geometry optimization.}

Visualized PQMN optimum structure is shown in Fig. 1. Also, the computed PQMN optimized bond lengths and bond angles using B3LYP/6-311G(d,p) are listed in Table 1. Experimental PQMN crystal structure has not been reported so far. Therefore, PQMN optimized structure can only be compared with other similar systems for which the crystallographic information is available. 


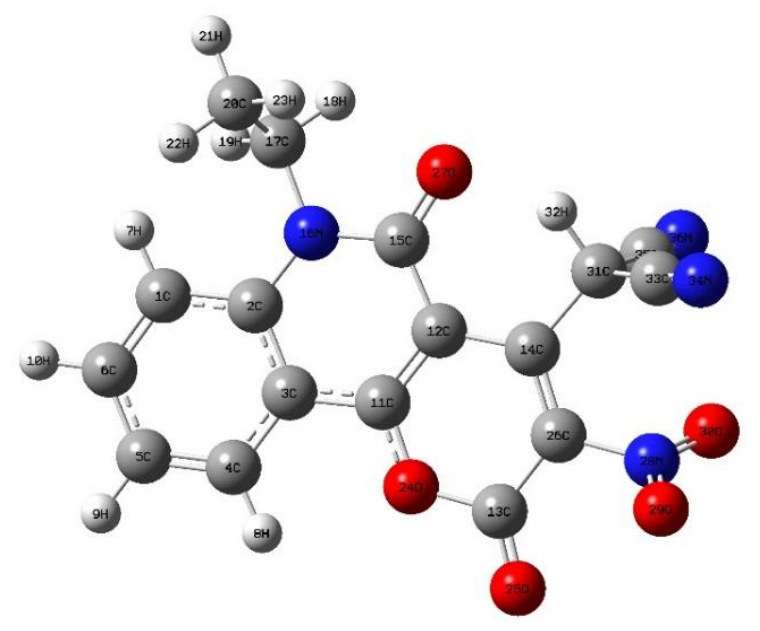

Figure 1. Optimized molecular structure of PQMN at B3LYP/6-311G(d,p).

Table 1. Optimized Structural Parameters for PQMN at B3LYP/6-311G(d,p). Bond Length $(\AA)$

\begin{tabular}{|c|c|c|c|c|c|c|c|}
\hline & \\
\hline $\mathrm{C}(1)-\mathrm{C}(2)$ & 1.4 & $\mathrm{~N}(28)-\mathrm{O}(29)$ & 1.2 & $\mathrm{C}(2)-\mathrm{C}(1)-\mathrm{C}(6)$ & 120.3 & $\mathrm{C}(12)-\mathrm{C}(15)-\mathrm{O}(27)$ & 123.8 \\
\hline $\mathrm{C}(1)-\mathrm{C}(6)$ & 1.4 & $\mathrm{~N}(28)-\mathrm{O}(30)$ & 1.2 & $\mathrm{C}(2)-\mathrm{C}(1)-\mathrm{H}(7)$ & 120.7 & $\mathrm{~N}(16)-\mathrm{C}(15)-\mathrm{O}(27)$ & 119.1 \\
\hline $\mathrm{C}(1)-\mathrm{H}(7)$ & 1.1 & $\mathrm{C}(31)-\mathrm{H}(32)$ & 1.1 & $\mathrm{C}(6)-\mathrm{C}(1)-\mathrm{H}(7)$ & 119 & $\mathrm{C}(2)-\mathrm{N}(16)-\mathrm{C}(15)$ & 123.7 \\
\hline $\mathrm{C}(2)-\mathrm{C}(3)$ & 1.4 & $\mathrm{C}(31)-\mathrm{C}(33)$ & 1.5 & $\mathrm{C}(1)-\mathrm{C}(2)-\mathrm{C}(3)$ & 118.2 & $\mathrm{C}(2)-\mathrm{N}(16)-\mathrm{C}(17)$ & 120.7 \\
\hline $\mathrm{C}(2)-\mathrm{N}(16)$ & 1.4 & $\mathrm{C}(31)-\mathrm{C}(35)$ & 1.5 & $\mathrm{C}(1)-\mathrm{C}(2)-\mathrm{N}(16)$ & 122.2 & $\mathrm{C}(15)-\mathrm{N}(16)-\mathrm{C}(17)$ & 115.5 \\
\hline $\mathrm{C}(3)-\mathrm{C}(4)$ & 1.4 & $\mathrm{C}(33)-\mathrm{N}(34)$ & 1.1 & $\mathrm{C}(3)-\mathrm{C}(2)-\mathrm{N}(16)$ & 119.6 & $\mathrm{~N}(16)-\mathrm{C}(17)-\mathrm{H}(18)$ & 106.2 \\
\hline$C(3)-C(11)$ & 1.4 & $\mathrm{C}(35)-\mathrm{N}(36)$ & 1.2 & $\mathrm{C}(2)-\mathrm{C}(3)-\mathrm{C}(4)$ & 120.4 & $\mathrm{~N}(16)-\mathrm{C}(17)-\mathrm{H}(19)$ & 107.7 \\
\hline $\mathrm{C}(4)-\mathrm{C}(5)$ & 1.4 & & & $\mathrm{C}(2)-\mathrm{C}(3)-\mathrm{C}(11)$ & 117.9 & $\mathrm{~N}(16)-\mathrm{C}(17)-\mathrm{C}(20)$ & 113 \\
\hline $\mathrm{C}(4)-\mathrm{H}(8)$ & 1.1 & & & $\mathrm{C}(4)-\mathrm{C}(3)-\mathrm{C}(11)$ & 121.7 & $\mathrm{H}(18)-\mathrm{C}(17)-\mathrm{H}(19)$ & 107.7 \\
\hline $\mathrm{C}(5)-\mathrm{C}(6)$ & 1.4 & & & $\mathrm{C}(3)-\mathrm{C}(4)-\mathrm{C}(5)$ & 120.5 & $\mathrm{H}(18)-\mathrm{C}(17)-\mathrm{C}(20)$ & 109.9 \\
\hline $\mathrm{C}(5)-\mathrm{H}(9)$ & 1.1 & & & $\mathrm{C}(3)-(4)-\mathrm{H}(8)$ & 118.5 & $\mathrm{H}(19)-\mathrm{C}(17)-\mathrm{C}(20)$ & 112 \\
\hline $\mathrm{C}(6)-\mathrm{H}(10)$ & 1.1 & & & $\mathrm{C}(5)-\mathrm{C}(4)-\mathrm{H}(8)$ & 121 & $\mathrm{C}(17)-\mathrm{C}(20)-\mathrm{H}(21)$ & 109.6 \\
\hline $\mathrm{C}(11)-\mathrm{C}(12)$ & 1.4 & & & $C(4)-C(5)-C(6)$ & 119.2 & $\mathrm{C}(17)-\mathrm{C}(20)-\mathrm{H}(22)$ & 112.1 \\
\hline $\mathrm{C}(11)-\mathrm{O}(24)$ & 1.3 & & & $\mathrm{C}(4)-\mathrm{C}(5)-\mathrm{H}(9)$ & 120.4 & $\mathrm{C}(17)-\mathrm{C}(20)-\mathrm{H}(23)$ & 110.3 \\
\hline $\mathrm{C}(12)-\mathrm{C}(14)$ & 1.5 & & & $\mathrm{C}(6)-\mathrm{C}(5)-\mathrm{H}(9)$ & 120.4 & $\mathrm{H}(21)-\mathrm{C}(20) \mathrm{H}(22)$ & 108.2 \\
\hline $\mathrm{C}(12)-\mathrm{C}(15)$ & 1.5 & & & $\mathrm{C}(1)-\mathrm{C}(6)-\mathrm{C}(5)$ & 121.3 & $\mathrm{H}(21)-\mathrm{C}(20)-\mathrm{H}(23)$ & 108 \\
\hline $\mathrm{C}(13)-\mathrm{O}(24)$ & 1.4 & & & $\mathrm{C}(1)-\mathrm{C}(6)-\mathrm{H}(10)$ & 118.9 & $\mathrm{H}(22)-\mathrm{C}(20)-\mathrm{H}(23)$ & 108.6 \\
\hline $\mathrm{C}(13)-\mathrm{O}(25)$ & 1.2 & & & $\mathrm{C}(5)-\mathrm{C}(6)-\mathrm{H}(10)$ & 119.8 & $\mathrm{C}(11)-\mathrm{O}(24)-\mathrm{C}(13)$ & 124.1 \\
\hline$C(13)-C(26)$ & 1.5 & & & $\mathrm{C}(3)-\mathrm{C}(11)-\mathrm{C}(12)$ & 123 & $\mathrm{C}(13)-\mathrm{C}(26)-\mathrm{C}(14)$ & 123.9 \\
\hline $\mathrm{C}(14)-\mathrm{C}(26)$ & 1.4 & & & $\mathrm{C}(3)-\mathrm{C}(11)-\mathrm{O}(24)$ & 114.7 & $\mathrm{C}(13)-\mathrm{C}(26)-\mathrm{N}(28)$ & 113.6 \\
\hline $\mathrm{C}(14)-\mathrm{C}(31)$ & 1.5 & & & $\mathrm{C}(12)-\mathrm{C}(11)-\mathrm{O}(24)$ & 122.3 & $\mathrm{C}(14)-\mathrm{C}(26)-\mathrm{N}(28)$ & 122.4 \\
\hline $\mathrm{C}(15)-\mathrm{N}(16)$ & 1.4 & & & $\mathrm{C}(11)-\mathrm{C}(12)-\mathrm{C}(14)$ & 117.8 & $\mathrm{C}(26)-\mathrm{N}(28)-\mathrm{O}(29)$ & 116.4 \\
\hline $\mathrm{C}(15)-\mathrm{O}(27)$ & 1.2 & & & $\mathrm{C}(11)-\mathrm{C}(12)-\mathrm{C}(15)$ & 118.4 & $\mathrm{C}(26)-\mathrm{N}(28)-\mathrm{O}(30)$ & 116.8 \\
\hline $\mathrm{N}(16)-\mathrm{C}(17)$ & 1.5 & & & $\mathrm{C}(14)-\mathrm{C}(12)-\mathrm{C}(15)$ & 123.7 & $\mathrm{O}(29)-\mathrm{N}(28)-\mathrm{O}(30)$ & 126.8 \\
\hline $\mathrm{C}(17)-\mathrm{H}(18)$ & 1.1 & & & $\mathrm{O}(24)-\mathrm{C}(13)-\mathrm{O}(25)$ & 118 & $\mathrm{C}(14)-\mathrm{C}(31)-\mathrm{H}(32)$ & 105.5 \\
\hline $\mathrm{C}(17)-\mathrm{H}(19)$ & 1.1 & & & $\mathrm{O}(24)-\mathrm{C}(13)-\mathrm{C}(26)$ & 113.3 & $\mathrm{C}(14)-\mathrm{C}(31)-\mathrm{C}(33)$ & 114.5 \\
\hline $\mathrm{C}(17)-\mathrm{C}(20)$ & 1.5 & & & $\mathrm{O}(25)-\mathrm{C}(13)-\mathrm{C}(26)$ & 128.6 & $\mathrm{C}(14)-\mathrm{C}(31)-\mathrm{C}(35)$ & 110.6 \\
\hline $\mathrm{C}(20)-\mathrm{H}(21)$ & 1.1 & & & $\mathrm{C}(12)-\mathrm{C}(14)-\mathrm{C}(26)$ & 118.5 & $\mathrm{H}(32)-\mathrm{C}(31)-\mathrm{C}(33)$ & 106.7 \\
\hline $\mathrm{C}(20)-\mathrm{H}(22)$ & 1.1 & & & $\mathrm{C}(12)-\mathrm{C}(14)-\mathrm{C}(31)$ & 119.6 & $\mathrm{H}(32)-\mathrm{C}(31)-\mathrm{C}(35)$ & 105.2 \\
\hline $\mathrm{C}(20)-\mathrm{H}(23)$ & 1.1 & & & $\mathrm{C}(26)-\mathrm{C}(14)-\mathrm{C}(31)$ & 121.9 & $\mathrm{C}(33)-\mathrm{C}(31)-\mathrm{C}(35)$ & 113.5 \\
\hline $\mathrm{C}(26)-\mathrm{N}(28)$ & 1.5 & & & $\mathrm{C}(12)-\mathrm{C}(15)-\mathrm{N}(16)$ & 117.1 & & \\
\hline
\end{tabular}

\subsection{Vibrational assignments.}

PQMN compound contains 36 atoms possesses 102 vibrational modes distributed as 58 $\mathrm{A}^{\prime}+44$ A considering Cs symmetry. To compare with the experimental data listed in Table 2, we have selected only 30 modes distributed as 23 A' +7 A". Note that mode A' denote in-plane and stretching vibrations during mode A"denote out-of-plane ones. The observed FT-IR spectrum's vibrational assignments are mainly based on theoretically predicted wavenumbers using B3LYP/6-311G (d,p) basis set [22]. The computed vibrational wavenumbers for PQMN 
have been scaled with a scaling factor 0.96. Both observed and computed FT-IR spectra at B3LYP/6-311G(d,p) basis set for PQMN are shown in Fig. 2.

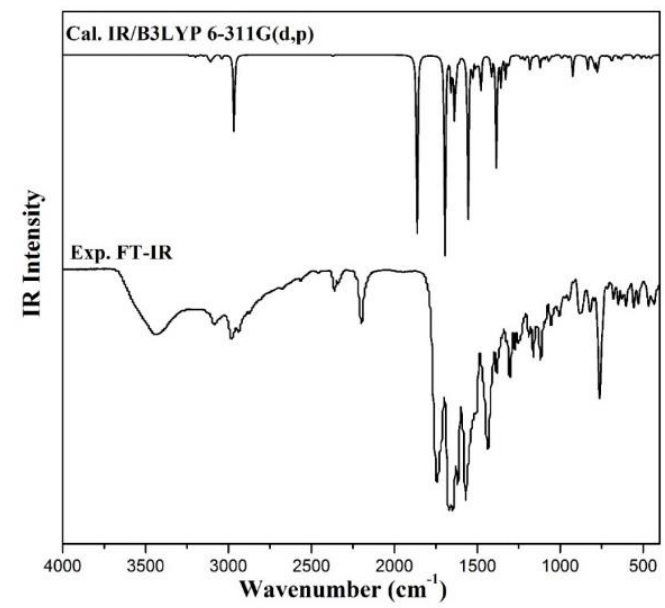

Figure 2. Experimental and calculated FT-IR spectra for PQMN at B3LYP/6-311G(d,p).

The computed vibrational wavenumbers at B3LYP/6-311G(d,p) are comparable to the experimental data. Despite the molecular structure (see Fig. 1) does not contain a hydroxyl group, our experimental FT-IR spectrum (see Fig. 2) contains broadband that appears at 3440 $\mathrm{cm}^{-1}$, which may be attributed to $\mathrm{O}-\mathrm{H}$ stretching vibration. Accordingly, PQMN compound is affected by air humidity. The absence of the vibrational mode of the $\mathrm{O}-\mathrm{H}$ group in our theoretical calculations confirmed this interpretation. The assignment could be achieved extensively as in the following:

\subsubsection{C-H vibrations.}

The calculated mode 30 is assigned to aromatic C-H stretching vibration at $3090 \mathrm{~cm}^{-1}$, comparable with the experimental data at $3083 \mathrm{~cm}^{-1}$ [23]. The calculated modes (28 \& 29) are assigned to symmetric and asymmetric C-H stretching vibration in $\mathrm{CH}_{3}$ at 2919 and $2994 \mathrm{~cm}^{-}$ ${ }^{1}$, which are in good agreement with experimental data at 2938 and $2981 \mathrm{~cm}^{-1}$, consequently. The computed modes $(15,16,17,18,19)$ are assigned to $\mathrm{C}-\mathrm{H}$ in plan bending vibrations at $1114,1150,1187,1260$, and $1277 \mathrm{~cm}^{-1}$, which are comparable to experimental data at 1118 , $1161,1189,1253$, and $1274 \mathrm{~cm}^{-1}$. The computed modes $(9,10,11)$ are assigned to C-H out of plane bending vibrations at 743, 761, and $842 \mathrm{~cm}^{-1}$ using B3LYP/6-311G(d,p), which are comparable to experimental data at 762,795 and $820 \mathrm{~cm}^{-1}$.

\subsection{2. $\mathrm{C} \equiv \mathrm{N}$ vibrations.}

The calculated modes $(26,27)$ are assigned to $\mathrm{C} \equiv \mathrm{N}$ stretching vibrations at 2272 and $2275 \mathrm{~cm}^{-1}$, comparable to the experimental values at 2199 and $2339 \mathrm{~cm}^{-1}$.

\subsection{3. $\mathrm{C}=\mathrm{O}, \mathrm{N}=\mathrm{O}, \mathrm{C}=\mathrm{C}$ vibrations.}

The computed modes $(24,25)$ are assigned to $\mathrm{C}=\mathrm{O}$ stretching vibrations at 1627 and $1789 \mathrm{~cm}^{-1}$, comparable to experimental data at 1670 and $1742 \mathrm{~cm}^{-1}$. The computed mode 23 is assigned to $\mathrm{N}=\mathrm{O}$ stretching vibration at $1573 \mathrm{~cm}^{-1}$, comparable to experimental data at 1648 $\mathrm{cm}^{-1}$. The calculated modes $(21,22)$ are assigned to $\mathrm{C}=\mathrm{C}$ stretching vibrations at 1493 and $1547 \mathrm{~cm}^{-1}$ using B3LYP/6-311G(d,p), comparable to experimental data 1570 and $1618 \mathrm{~cm}^{-1}$. 


\subsubsection{Methyl group vibrations.}

The computed mode 20 is assigned to $\mathrm{CH}_{3}$ deformation at $1435 \mathrm{~cm}^{-1}$, comparable to experimental data at $1438 \mathrm{~cm}^{-1}[24]$.

\subsubsection{C-C, C-O, C-N vibrations.}

The calculated mode 12 is assigned to $\mathrm{C}-\mathrm{C}$ stretching vibrations at $887 \mathrm{~cm}^{-1}$, comparable to experimental data at $883 \mathrm{~cm}^{-1}$. The computed mode 13 is assigned to $\mathrm{C}-\mathrm{N}$ stretching vibrations at $951 \mathrm{~cm}^{-1}$ comparable to experimental data at $948 \mathrm{~cm}^{-1}$. The calculated mode 14 is assigned to $\mathrm{C}-\mathrm{O}$ stretching vibrations at $999 \mathrm{~cm}^{-1}$, comparable to experimental data at $1007 \mathrm{~cm}^{-1}$. The computed modes $(5,6,7,8)$ are assigned to $\mathrm{C}-\mathrm{C}, \mathrm{C}-\mathrm{O}$, and $\mathrm{C}-\mathrm{N}$ in-plane vibrations at $609,662,677$, and $699 \mathrm{~cm}^{-1}$, which are comparable to the experimental data at $603,650,679$, and $715 \mathrm{~cm}^{-1}$. The calculated modes $(1,2,3,4)$ are assigned to $\mathrm{C}-\mathrm{C}, \mathrm{C}-\mathrm{O}$, and $\mathrm{C}-\mathrm{N}$ out of plane vibrations at $429,448,531$, and $538 \mathrm{~cm}^{-1}$, which are comparable to the experimental data at $433,467,529$, and $557 \mathrm{~cm}^{-1}$.

Table 2. Experimental and Computational Calculated Vibrational Wavenumbers (Harmonic Frequency $\left(\mathrm{cm}^{-1}\right)$ ), IR Intensities, Species, and Assignments for PQMN at B3LYP/6-311G(d,p).

\begin{tabular}{|c|c|c|c|c|c|c|c|}
\hline \multirow{3}{*}{ No } & \multirow{3}{*}{ Exp. } & \multicolumn{4}{|c|}{ B3LYP/6-311G (d,p) } & \multirow{3}{*}{ Species } & \multirow{3}{*}{$\begin{array}{l}\text { Vibrational } \\
\text { Assignment }\end{array}$} \\
\hline & & \multicolumn{2}{|c|}{ Wavenumber } & \multicolumn{2}{|c|}{ IR intensity } & & \\
\hline & & Unscaled & Scaled & Rel. & Abs. & & \\
\hline 1 & 433 & 447 & 429 & 6 & 1 & A" & \multirow{4}{*}{$\gamma \mathrm{C}-\mathrm{C}+\gamma^{-} \mathrm{C}-\mathrm{O}+\gamma^{-} \mathrm{C}-\mathrm{N}$} \\
\hline 2 & 467 & 467 & 448 & 3 & 0 & $\mathrm{~A}^{\prime \prime}$ & \\
\hline 3 & 529 & 553 & 531 & 4 & 1 & $\mathrm{~A}^{\prime \prime}$ & \\
\hline 4 & 557 & 560 & 538 & 9 & 2 & $\mathrm{~A}^{\prime \prime}$ & \\
\hline 5 & 603 & 634 & 609 & 10 & 2 & $\mathrm{~A}^{\prime}$ & \multirow{4}{*}{$\beta \mathrm{C}-\mathrm{C}+\beta \mathrm{C}-\mathrm{O}+\beta \mathrm{C}-\mathrm{N}$} \\
\hline 6 & 650 & 689 & 662 & 25 & 4 & $\mathrm{~A}^{\prime}$ & \\
\hline 7 & 679 & 706 & 677 & 4 & 1 & $\mathrm{~A}^{\prime}$ & \\
\hline 8 & 715 & 728 & 699 & 3 & 1 & $\mathrm{~A}^{\prime}$ & \\
\hline 9 & 762 & 774 & 743 & 63 & 11 & $\mathrm{~A}^{\prime \prime}$ & \multirow{3}{*}{$\mathrm{\gamma C}-\mathrm{H}$} \\
\hline 10 & 795 & 793 & 761 & 34 & 6 & A" & \\
\hline 11 & 820 & 877 & 842 & 1 & 0 & $\mathrm{~A}^{\prime \prime}$ & \\
\hline 12 & 883 & 924 & 887 & 60 & 10 & $\mathrm{~A}^{\prime}$ & oC-C \\
\hline 13 & 948 & 991 & 951 & 13 & 2 & $\mathrm{~A}^{\prime}$ & vC-N \\
\hline 14 & 1007 & 1041 & 999 & 4 & 1 & $\mathrm{~A}^{\prime}$ & vC-O \\
\hline 15 & 1118 & 1160 & 1114 & 7 & 1 & $\mathrm{~A}^{\prime}$ & \multirow{5}{*}{$\beta C-H$} \\
\hline 16 & 1161 & 1198 & 1150 & 0 & 0 & $\mathrm{~A}^{\prime}$ & \\
\hline 17 & 1189 & 1236 & 1187 & 16 & 3 & $\mathrm{~A}^{\prime}$ & \\
\hline 18 & 1253 & 1312 & 1260 & 42 & 7 & $\mathrm{~A}^{\prime}$ & \\
\hline 19 & 1274 & 1330 & 1277 & 63 & 11 & $\mathrm{~A}^{\prime}$ & \\
\hline 20 & 1438 & 1495 & 1435 & 24 & 4 & $\mathrm{~A}^{\prime}$ & $\mathrm{CH}_{3}$ deformation \\
\hline 21 & 1570 & 1555 & 1493 & 509 & 86 & $\mathrm{~A}^{\prime}$ & \multirow{2}{*}{$\mathrm{vC}=\mathrm{C}$} \\
\hline 22 & 1618 & 1611 & 1547 & 14 & 2 & $\mathrm{~A}^{\prime}$ & \\
\hline 23 & 1648 & 1639 & 1573 & 169 & 29 & $\mathrm{~A}^{\prime}$ & $v \mathrm{~N}=\mathrm{O}$ \\
\hline 24 & 1670 & 1695 & 1627 & 590 & 100 & $\mathrm{~A}^{\prime}$ & \multirow{2}{*}{$v \mathrm{C}=\mathrm{O}$} \\
\hline 25 & 1742 & 1863 & 1789 & 559 & 95 & $\mathrm{~A}^{\prime}$ & \\
\hline 26 & 2199 & 2366 & 2272 & 1 & 0 & $\mathrm{~A}^{\prime}$ & \multirow{2}{*}{$v \mathrm{C} \equiv \mathrm{N}$} \\
\hline 27 & 2339 & 2370 & 2275 & 5 & 1 & $\overline{\mathrm{A}^{\prime}}$ & \\
\hline 28 & 2938 & 3041 & 2919 & 16 & 3 & $\mathrm{~A}^{\prime}$ & $v_{s} \mathrm{C}-\mathrm{H}$ in $\mathrm{CH}_{3}$ \\
\hline 29 & 2981 & 3119 & 2994 & 18 & 3 & $\mathrm{~A}^{\prime}$ & $\mathrm{v}_{\mathrm{as}} \mathrm{C}-\mathrm{H}$ in $\mathrm{CH}_{3}$ \\
\hline 30 & 3083 & 3218 & 3090 & 2 & 0 & $\mathrm{~A}^{\prime}$ & vC-H (aromatic) \\
\hline
\end{tabular}

$v$ (stretching); $v_{\mathrm{s}}$ (Symmetric Stretching); $v_{\mathrm{as}}$ (Asymmetric Stretching); $\quad \beta$ (in-plane bending); $\gamma$ (out of plane bending)

\subsection{Thermo-chemistry and related physical insights.}

According to the molecular orbital theory, using FMOs energies, the ionization energy (I) and electron affinity (A) can be expressed by as $\mathrm{I}=-\mathrm{E}_{\text {Hомо }}$ and $\mathrm{A}=$-ELumo. Also, The 
global hardness $(\eta)$ and electronic chemical potential $(\mu)$ are given by $\eta=1 / 2$ (ELumo-Eномо) and $\mu=1 / 2\left(\right.$ ELumo + Eномо). The global electrophilicity index, $\psi=\mu^{2} / 2 \eta$ and softness, $\zeta=1 / \eta$ $[25,26]$. Also, many calculated thermo-chemical parameters such as total energy, zero-point vibrational energy, rotational constants, entropy at room temperature, specific heat $\mathrm{Cv}$, overall dipole moment, nuclear repulsion energy, and HOMO-LUMO band gap for PQMN at B3LYP/6-311G(d,p) are listed in Table 3.

Table 3. The Optimized Calculations of Total Energies (a.u), Zero Point Vibrational Energies $\left(\mathrm{kcal} \mathrm{mol}^{-1}\right)$, Rotational Constants $(\mathrm{GHz})$, Entropies $\left(\mathrm{cal} \mathrm{k}^{-1}\right)$, Specific Heat $\mathrm{C}_{\mathrm{V}}\left(\mathrm{cal} \mathrm{k}^{-1}\right)$, Total Dipole Moment (Debye), Nuclear Repulsion Energy (eV), E $\mathrm{LuMO}_{\mathrm{H}}, \mathrm{E}_{\mathrm{HOMO}}(\mathrm{eV})$, HOMO-LUMO Energy Gap (eV), Ionization Energy (eV), Electron Affinity (eV), Global Hardness (eV), Electronic Chemical Potential (eV), Global Electrophilicity Index (eV) and finally softness $\left(\mathrm{eV}^{-1}\right)$ for PQMN at B3LYP/6-311G(d,p).

\begin{tabular}{|c|c|c|}
\hline \multirow{2}{*}{ Parameter } & \multicolumn{2}{|l|}{ B3LYP } \\
\hline & \multicolumn{2}{|l|}{ 6-311G (d,p) } \\
\hline Total Energy & \multicolumn{2}{|c|}{-34061.424046298} \\
\hline Zero Point Energy & \multicolumn{2}{|c|}{157.20874} \\
\hline \multirow[t]{3}{*}{ Rotational Constants } & \multicolumn{2}{|l|}{0.34951} \\
\hline & \multicolumn{2}{|l|}{0.16175} \\
\hline & \multicolumn{2}{|l|}{0.12219} \\
\hline \multicolumn{3}{|l|}{ Entropy } \\
\hline Total & \multicolumn{2}{|l|}{156.979} \\
\hline Transational & \multicolumn{2}{|l|}{43.453} \\
\hline Vibrational & \multicolumn{2}{|l|}{78.430} \\
\hline Rotational & \multicolumn{2}{|l|}{35.097} \\
\hline Nuclear repulsion energy & \multicolumn{2}{|l|}{$6.2 \times 10^{4}$} \\
\hline Specific Heat at Constant Volume & \multicolumn{2}{|l|}{81} \\
\hline Dipole Moment & \multicolumn{2}{|l|}{13.3} \\
\hline \multirow[t]{2}{*}{ Spin } & \multicolumn{2}{|l|}{ Singlet } \\
\hline & Beta (spin $\downarrow$ ) & Alpha (spin $\uparrow)$ \\
\hline \multirow{2}{*}{ No. of Electrons } & 90 & 90 \\
\hline & Beta MOs & Alpha MOs \\
\hline HOMO-LUMO energy gap & 3.7 & 3.7 \\
\hline Ionization energy (I) & \multicolumn{2}{|l|}{7.4} \\
\hline Electron Affinity (A) & \multicolumn{2}{|l|}{3.7} \\
\hline Global Hardness $(\eta)$ & \multicolumn{2}{|l|}{1.9} \\
\hline Chemical Potential $(\mu)$ & \multicolumn{2}{|l|}{5.5} \\
\hline Global Electrophilicity Index $(\psi)$ & \multicolumn{2}{|l|}{8} \\
\hline Softness $(\zeta)$ & \multicolumn{2}{|l|}{0.5} \\
\hline
\end{tabular}

\subsection{HOMO/LUMO analyses.}

FMOs, including the highest occupied molecular orbitals (HOMOs) and lowest unoccupied molecular orbitals (LUMOs), reflect the studied molecule's chemical activity. Since HOMO is a measure of the ease of electron loss, and LUMO is a measure of the ease of electron gain. Therefore, HOMO/LUMO molecular orbitals are considered an accurate indicator of electron transport chargeability in molecular systems [27-32]. A small HOMO characterizes the conjugated molecules-LUMO separation, which is the result of a significant degree of intramolecular charge transfer (ICT) from the end-capping electron-donor groups to the efficient electron-acceptor ones through-conjugated path [33-40]. PQMN Frontiers' molecular orbitals split into two district alpha (spin $\uparrow$ ) and beta (spin $\downarrow$ ) states with the same energy $3.7 \mathrm{eV}$, although its singlet spins state as shown in Fig. 3. Such results emphasize both degeneracy and diamagnetic properties of PQMN. Fig. 4 shows the calculated density of state (DOS) spectrum for PQMN at B3LYP/6-311G(d,p). Also, the calculated dipole moment value (13.3 Debye) for PQMN explains the mystery behind its reactive tendency with the nearby media. PQMN is a promising structure for degenerate diamagnetic semiconductors that can be easily used for optoelectronic manufactured devices such as solar cells and spintronic devices. 


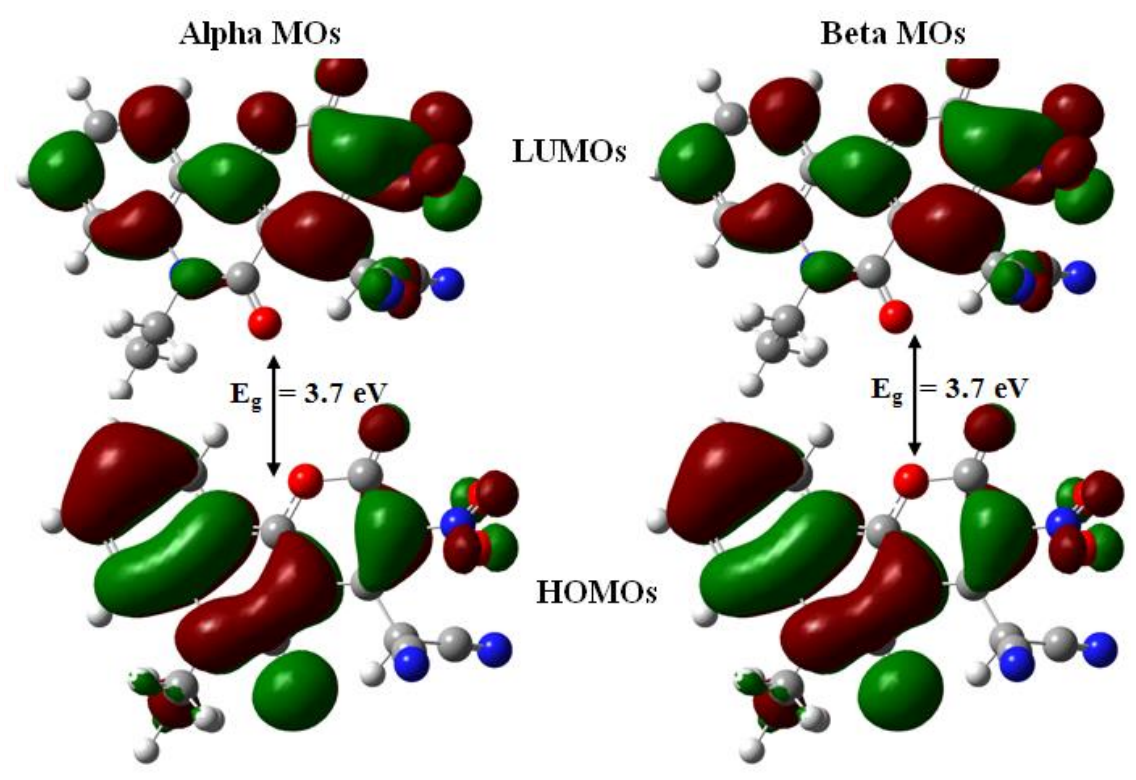

Figure 3. HOMO/LUMO Energy Gaps for PQMN at B3LYP/6-311G(d,p).

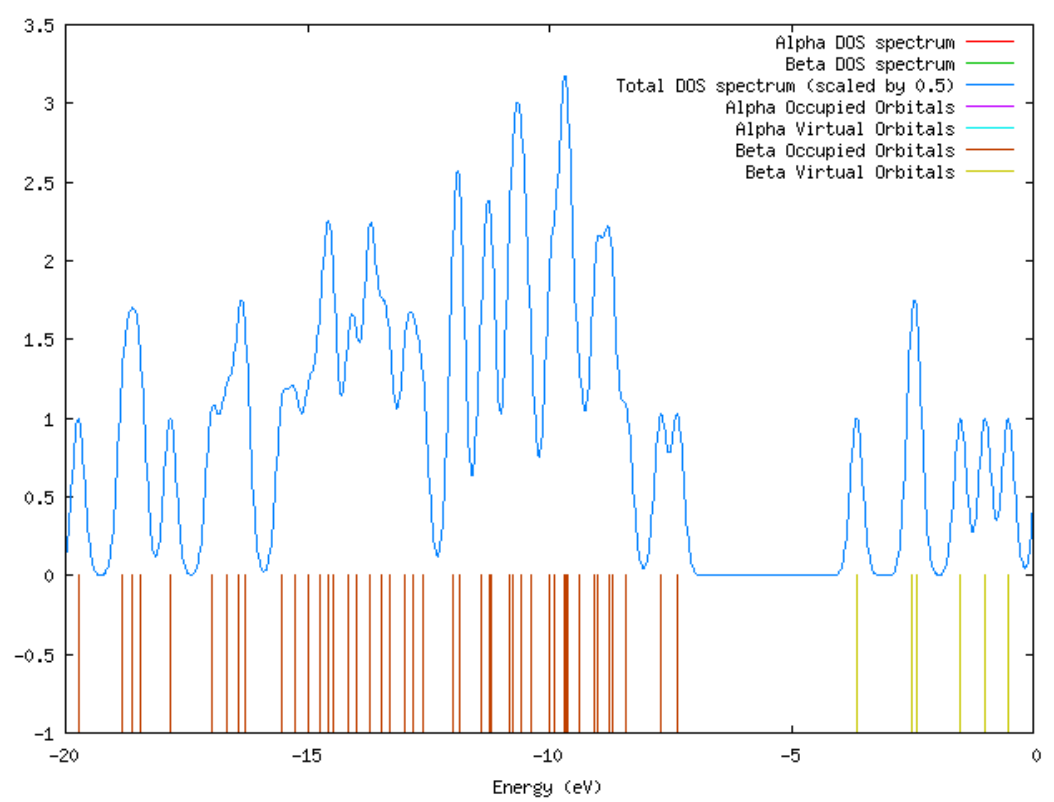

Figure 4. Density of state (DOS) spectrum for PQMN at B3LYP/6-311G(d,p).

\subsection{Polarizability and first order hyperpolarizability calculations.}

In order to investigate the relationships among molecular structures and non-linear optical properties (NLO), the polarizabilities and first-order hyperpolarizabilities of PQMN compound were calculated using B3LYP/6-311G(d,p) basis set, based on the finite-field approach. The polarizability and hyperpolarizability tensors $\left(\alpha_{\mathrm{xx}}, \alpha_{\mathrm{xy}}, \alpha_{\mathrm{yy}}, \alpha_{\mathrm{xz}}, \alpha_{\mathrm{yz}}, \alpha_{\mathrm{zz}}\right.$ and $\beta_{\mathrm{xxx}}$, $\left.\beta_{x x y}, \beta_{x y y}, \beta_{y y y}, \beta_{x x z}, \beta_{x y z}, \beta_{y y z}, \beta_{x z z}, \beta_{y z z}, \beta_{z z z}\right)$ are obtained by a frequency job output Gaussian file. The mean polarizability $\left(\alpha_{\mathrm{tot}}\right)$, the anisotropy of polarizability $(\Delta \alpha)$ and the average value of the first order hyperpolarizability $\left(\beta_{\text {tot }}\right)$ can be calculated using the equations [41-45]:

$$
\begin{aligned}
& \alpha_{\mathrm{tot}}=\frac{\alpha_{\mathrm{xx}}+\alpha_{\mathrm{yy}}+\alpha_{\mathrm{zz}}}{3} \\
& \Delta \alpha=\frac{1}{\sqrt{2}}\left[\left(\alpha_{x x}-\alpha_{y y}\right)^{2}+\left(\alpha_{y y}-\alpha_{z z}\right)^{2}+\left(\alpha_{z z}-\alpha_{x x}\right)^{2}+6 \alpha_{y z}^{2}+6 \alpha_{x y}^{2}+6 \alpha_{x z}^{2}\right]^{1 / 2}
\end{aligned}
$$


$\beta_{t o t}=\left[\left(\beta_{x x x}+\beta_{x y y}+\beta_{x z z}\right)^{2}+\left(\beta_{y y y}+\beta_{y z z}+\beta_{y x x}\right)^{2}+\left(\beta_{z z z}+\beta_{z x x}+\beta_{z y y}\right)^{2}\right]^{1 / 2}$

The higher values of dipole moment, molecular polarizability, and first-order hyperpolarizability are important indicators of highly active NLO properties of PQMN. Believing this, we may expect the usage of the compound under investigation in non-linear devices. The first order hyperpolarizability $\left(\beta_{\mathrm{tot}}\right)$ and the components of hyperpolarizability $\beta_{\mathrm{x}}$, $\beta_{\mathrm{y}}$ and $\beta_{\mathrm{z}}$ of PQMN along with related properties $\left(\Delta \alpha\right.$ and $\alpha_{\mathrm{tot}}$ ) are reported in Table 4 . The calculated values have been converted into electronic units (esu) $)\left(\alpha ; 1\right.$ a.u. $=0.1482 \times 10^{-24}$ esu, $\beta ; 1$ a.u. $\left.=8.6393 \times 10^{-33} \mathrm{esu}\right)$. The calculated polarizability and anisotropy of the polarizability of PQMN are $34.74 \times 10^{-24}$ and $25.39 \times 10^{-24}$ esu, respectively. The magnitude of the molecular hyperpolarizability $(\beta)$ is one of the important key factors in an NLO system [46$48]$. The calculated first-order hyperpolarizability value $\left(\beta_{\text {tot }}\right)$ of PQMN is equal to $8.59 \times 10^{-}$ ${ }^{30} \mathrm{esu}$, which is 23 times higher than urea ( $\left.\beta_{\text {urea }}=0.3728 \times 10^{-30} \mathrm{esu}\right)$. PQMN is a promising material for optoelectronic device applications as it shows a good NLO response.

Table 4. Mean polarizability $\alpha_{\text {tot }}\left(\mathrm{x} 10^{-24} \mathrm{esu}\right)$, anisotropy polarizability $\Delta \alpha$ (x10 $\left.{ }^{-24} \mathrm{esu}\right)$ and first-order hyperpolarizability $\beta_{\text {tot }}\left(\mathrm{x} 10^{-30} \mathrm{esu}\right)$ for HPHP based on B3LYP/6-311G(d,p) basis set.

\begin{tabular}{l|l|l|l|l} 
Parameters & Values & & Parameter & Value \\
\hline$\alpha_{x x}$ & 48.66 & & $\beta_{x x x}$ & 11.82 \\
\hline$\alpha_{x y}$ & -1.26 & & $\beta_{x x y}$ & 0.90 \\
\hline$\alpha_{y y}$ & 35.90 & & $\beta_{x y y}$ & -2.89 \\
\hline$\alpha_{x z}$ & -1.11 & & $\beta_{y y y}$ & 0.42 \\
\hline$\alpha_{y z}$ & -0.86 & & $\beta_{x x z}$ & -0.19 \\
\hline$\alpha_{z z}$ & 19.66 & & $\beta_{x y z}$ & 0.14 \\
\hline$\alpha_{\mathrm{tot}}$ & 34.74 & & $\beta_{y y z}$ & 0.01 \\
\hline$\Delta \alpha$ & 25.39 & & $\beta_{x z z}$ & -0.41 \\
\hline & & & $\beta_{y z z}$ & -0.17 \\
\hline & & & $\beta_{z z z}$ & -0.08 \\
\hline & & & $\beta_{\text {tot }}$ & 8.59
\end{tabular}

\section{Conclusions}

Quantum computations Results conclude both degeneracy and diamagnetic properties of PQMN based on FMOs split into two distinguished alpha (spin $\uparrow$ ) and beta ( $\operatorname{spin} \downarrow$ ) states with the same energy $3.7 \mathrm{eV}$, although its singlet spins state. Moreover, the calculated dipole moment (DM) value (13.3 Debye) for PQMN explains the mystery behind its reactive tendency with the nearby media. Also, the calculated first-order hyperpolarizability value $\left(\beta_{\text {tot }}\right)$ of PQMN is equal to $8.59 \times 10^{-30} \mathrm{esu}$, which is 23 times higher than urea ( $\beta_{\text {urea }}=0.3728 \times 10^{-30} \mathrm{esu}$ ). $\mathrm{PQMN}$ is a promising material for optoelectronic device applications as it shows a good NLO response. PQMN is a unique model for a degenerate diamagnetic semiconductor that can be easily used for optoelectronic manufactured devices such as solar cells and spintronic devices. Comparison between experimental and theoretical spectra confirmed the suitability of the presented level of theory for the investigated compound.

\section{Funding}

This research received no external funding.

\section{Acknowledgments}

This research has no acknowledgment. 


\section{Conflicts of Interest}

The authors declare no conflict of interest.

\section{References}

1. Klimovich, I.V.; Zhilenkov, A.V.; Kuznetsova, L.I.; Frolova, L.A.; Yamilova, O.R.; Troyanov, S.I.; Lyssenko, K.A.; Troshin, P.A. Novel functionalized indigo derivatives for organic electronics. Dyes Pigments 2021, 186, 108966, https://doi.org/10.1016/j.dyepig.2020.108966.

2. Li, J.-S.; Huang, Y.-W.; Lin, Y.-C.; Chen, F.-H.; Chen, W.-C.; Chueh, C.-C. Exploring the effect of the spacer structure in the heterocyclic ring-fused isoindigo-based conjugated polymer on the chargetransporting property. Journal of Polymer Research 2021, 28, 1-12, https://doi.org/10.1007/s10965-02102417-0.

3. Xiao, X.; Shao, B.X.; Lu, Y.J.; Cao, Q.Q.; Xia, C.N.; Chen, F.E.; Catalysis. Recent Advances in symmetric Organomulticatalysis. Advanced Synthesis 2021, 363, 352-387, https://doi.org/10.1002/adsc.202000961.

4. Zhou, W.; Yutronkie, N.J.; Lessard, B.H.; Brusso, J.L. From chemical curiosity to versatile building blocks: unmasking the hidden potential of main-group phthalocyanines in organic field-effect transistors. Materials Advances 2021, https://doi.org/10.1039/D0MA00864H.

5. Al-Shemmeri, T.; Packer, N. Building Services Engineering: Smart and Sustainable Design for Health and Wellbeing; John Wiley \& Sons: 2021.

6. Wu, Y.; Huo, D.; Chen, G.; Yan, A. SAR and QSAR research on tyrosinase inhibitors using machine learning methods. SAR QSAR in Environmental Research 2021, 1-26, https://doi.org/10.1080/1062936X.2020.1862297.

7. Shaik, M.S.; Nadiveedhi, M.R.; Gundluru, M.; Narreddy, A.K.R.; Thathireddy, K.R.; Ramakrishna, R.; Cirandur, S.R. 2-Amino-3-cyano-4H-chromene-4-ylphosphonates as potential antiviral agents: Synthesis, in ovo and in silico approach. Journal of Heterocyclic Chemistry 2021, 58, 137-152, https://doi.org/10.1002/jhet.4154.

8. Basha, A.F.; Khan, F.L.A.; Muthu, S.; Raja, M. Computational evaluation on molecular structure (Monomer, Dimer), RDG, ELF, electronic (HOMO-LUMO, MEP) properties, and spectroscopic profiling of 8Quinolinesulfonamide with molecular docking studies. Computational Theoretical Chemistry 2021, 113169, https://doi.org/10.1016/j.comptc.2021.113169.

9. El-Mansy, M. FT-IR, FT-Raman Spectra and Ab Initio HF, DFT Vibrational Analysis of P-methyl acetanilide. Journal of Applied Sciences Research 2009, 5, 1977-1987.

10. El-Mansy, M.A.M.; El-Nahass, M.M.; Khusayfan, N.M.; El-Menyawy, E.M. DFT approach for FT-IR spectra and HOMO-LUMO energy gap for N-(p-dimethylaminobenzylidene)-p-nitroaniline (DBN). Spectrochimica Acta Part A: Molecular and Biomolecular Spectroscopy 2013, 111, 217-222, https://doi.org/10.1016/j.saa.2013.04.018.

11. El-Mansy, M.A.M.; Ismail, M.M. On the spectroscopic analyses of 3-(4-Hydroxy-1-methyl-2-oxo-1,2dihydro-quinolin-3-yl)-2-nitro-3-oxo-propionic acid (HMQNP). Spectrochimica Acta Part A: Molecular and Biomolecular Spectroscopy 2015, 135, 704-709, https://doi.org/10.1016/j.saa.2014.07.033.

12. El-Mansy, M.A.M.; Yahia, I.S. Spectroscopic notes of Methyl Red (MR) dye. Spectrochimica Acta Part A: Molecular and Biomolecular Spectroscopy 2014, 130, 59-63, https://doi.org/10.1016/j.saa.2014.03.113.

13. El-Nahass, M.M.; Kamel, M.A.; El-Barbary, A.A.; El-Mansy, M.A.M.; Ibrahim, M. FT-IR spectroscopic analyses of 3-Methyl-5-Pyrazolone (MP). Spectrochimica Acta Part A: Molecular and Biomolecular Spectroscopy 2013, 111, 37-41, https://doi.org/10.1016/j.saa.2013.03.072.

14. Ibrahim, M.; El-Barbary, A.A.; El-Nahass, M.M.; Kamel, M.A.; El-Mansy, M.A.M.; Asiri, A.M. On the spectroscopic analyses of (E)-3-(dicyclopropyl methylene)-dihydro-4-[1-(2,5 dimethylfuran-3-yl) ethylidene]furan-2,5-dione. Spectrochimica Acta Part A: Molecular and Biomolecular Spectroscopy 2012, 87, 202-208, https://doi.org/10.1016/j.saa.2011.11.039.

15. Ibrahim, M.; El-Nahass, M.M.; Kamel, M.A.; El-Barbary, A.A.; Wagner, B.D.; El-Mansy, M.A.M. On the spectroscopic analyses of thioindigo dye. Spectrochimica Acta Part A: Molecular and Biomolecular Spectroscopy 2013, 113, 332-336, https://doi.org/10.1016/j.saa.2013.05.014.

16. Ismail, M.M.; Morsy, G.M.; Mohamed, H.M.; El-Mansy, M.A.M.; Abd-Alrazk, M.M.A. FT-IR spectroscopic analyses of 4-hydroxy-1-methyl-3-[2-nitro-2-oxoacetyl-2(1H)quinolinone (HMNOQ). Spectrochimica Acta Part A: Molecular and Biomolecular Spectroscopy 2013, 113, 191-195, https://doi.org/10.1016/j.saa.2013.04.117.

17. Soliman, H.S.; Eid, K.M.; Ali, H.A.M.; Atef, S.M.; El-Mansy, M.A.M. Vibrational spectroscopic analysis of 2-chloro-5-(2,5-dimethoxy-benzylidene)-1,3-diethyl-dihydro-pyrimidine-4,6(1H,5H)-dione. Spectrochimica Acta Part A: Molecular and Biomolecular Spectroscopy 2012, 97, 1079-1084, https://doi.org/10.1016/j.saa.2012.07.104. 
18. Soliman, H.S.; Eid, K.M.; Ali, H.A.M.; El-Mansy, M.A.M.; Atef, S.M. FT-IR spectroscopic analyses of 2(2-furanylmethylene) propanedinitrile. Spectrochimica Acta Part A: Molecular and Biomolecular Spectroscopy 2013, 105, 545-549, https://doi.org/10.1016/j.saa.2012.12.051.

19. Hassnin, H. Nucleophilic substitution and ring transformation reactions with 4-chloro-6-ethyl-3nitropyrano[3,2-c]quinoline-2,5(6H)-dione. Arkivoc 2012, http://dx.doi.org/10.3998/ark.5550190.0013.634.

20. Frisch, M.J.; Schlegel, G.W.T.H.B.; Scuseria, G.E.; Robb, M.A.; Cheeseman, J.R.; Montgomery, Jr.J.A.; Vreven, T.; Kudin, K.N.; Burant, J.C.; Millam, J.M.; Iyengar, S.S.; Tomasi, J.; Barone, V.; Mennucci, B.; Cossi, M.; Scalmani, G.; Rega, N.; Petersson, G.A.; Nakatsuji, H.; Hada, M.; Ehara, M.; Toyota, K.; Fukuda, R.; Hasegawa, J.; Ishida, M.; Nakajima, T.; Honda, Y.; Kitao, O.; Nakai, H.; Klene, M.; Li, X.; Knox, J.E.; Hratchian, H.P.; Cross, J.B.; Adamo, C.; Jaramillo, J.; Gomperts, R.; Stratmann, R.E.; Yazyev, O.; Austin, A.J.; Cammi, R.; Pomelli, C.; Ochterski, J.W.; Ayala, P.Y.; Morokuma, K.; Voth, G.A.; Salvador, P.; Dannenberg, J.J.; Zakrzewski, V.G.; Dapprich, S.; Daniels, A.D.; Strain, M.C.; Farkas, O.; Malick, D.K.; Rabuck, A.D.; Raghavachari, K.; Foresman, J.B.; Ortiz, J.V.; Cui, Q.; Baboul, A.G.; Clifford, S.; Cioslowski, J.; Stefanov, B.B.; Liu, G.; Liashenko, A.; Piskorz, P.; Komaromi, I.; Martin, R.L.; Fox, D.J.; Keith, T.; AlLaham, A.M.; Peng, C.Y.; Nanayakkara, A.; Challacombe, M.; Gill, P.M.W.; Johnson, B.; Chen, W.; Wong, M.W.; Gonzalez, C.; Pople, J.A. Inc., Wallingford CT 2009.

21. Frisch, A.; Dennington, R.; Keith, T.; Millam, J.; Nielsen, A.; Holder, A.; Hiscocks, J. Gaussian Inc. Wallingford, CT, USA 2009.

22. El-Mansy, M.A.M. Quantum chemical studies on structural, vibrational, non-linear optical properties and chemical reactivity of indigo carmine dye. Spectrochimica Acta Part A: Molecular and Biomolecular Spectroscopy 2017, 183, 284-290, https://doi.org/10.1016/j.saa.2017.04.047.

23. Duan, H.; Zhu, C.; Li, Y.; Zhang, H.; Zhang, S.; Xiao, F.; Amirkhanian, S. Effect of crumb rubber percentages and bitumen sources on high-temperature rheological properties of less smell crumb rubber modified bitumen. Construction Building Materials 2021, 277, 122248, https://doi.org/10.1016/j.conbuildmat.2021.122248.

24. Sardon, S.N.F.; Rahman, N.M.M.A.; Karim, M.R.; Zahid, N.I.; Salleh, N.M. Effects of lateral methyl and terminal substituents on thermal, mesomorphic and optical properties of azo-ester mesogens. Journal of Molecular Structure 2021, 1225, 129112, https://doi.org/10.1016/j.molstruc.2020.129112.

25. Almuqrin, A.H.; Al-Otaibi, J.S.; Mary, Y.S.; Mary, Y.S. DFT computational study towards investigating psychotropic drugs, promazine and trifluoperazine adsorption on graphene, fullerene and carbon cyclic ring nanoclusters. Spectrochimica Acta Part A: Molecular Biomolecular Spectroscopy 2021, 246, 119012, https://doi.org/10.1016/j.saa.2020.119012.

26. Gulácsi, M.; El-Mansy, M.A.M.; Gulácsi, Z. Electron-phonon interactions in conducting polymers. Philosophical Magazine Letters 2016, 96, 67-75, https://doi.org/10.1080/09500839.2016.1150611.

27. Motamarri, P.; Das, S.; Rudraraju, S.; Ghosh, K.; Davydov, D.; Gavini, V. DFT-FE - A massively parallel adaptive finite-element code for large-scale density functional theory calculations. Computer Physics Communications 2020, 246, https://doi.org/10.1016/j.cpc.2019.07.016.

28. Lgaz, H.; Salghi, R.; Masroor, S.; Kim, S.-H.; Kwon, C.; Kim, S.Y.; Yang, Y.-J.; Chung, I.-M. Assessing corrosion inhibition characteristics of hydrazone derivatives on mild steel in $\mathrm{HCl}$ : Insights from electronicscale DFT and atomic-scale molecular dynamics. Journal of Molecular Liquids 2020, 308, https://doi.org/10.1016/j.molliq.2020.112998.

29. Rajamani, P.; Vijayakumar, V.; Nagaraaj, P.; Sundaraganesan, N. Synthesis, Characterization, Spectroscopic, DFT and Molecular Docking Studies of 3-(3,4-Dihydroxyphenyl)-1-Phenyl-3(Phenylamino)Propan-1-One. Polycyclic Aromatic Compounds 2020, 1-21, https://doi.org/10.1080/10406638.2020.1837190.

30. Montoro, O.R.; Tortajada, J.; Lobato, Á.; Baonza, V.G.; Taravillo, M. Theoretical (DFT) and experimental (Raman and FTIR) spectroscopic study on communic acids, main components of fossil resins. Spectrochimica Acta Part A: Molecular and Biomolecular Spectroscopy 2020, 224, https://doi.org/10.1016/j.saa.2019.117405.

31. Zhang, C.; Cao, H.; Wang, C.; He, M.; Zhan, W.; Guo, Y. Catalytic mechanism and pathways of 1, 2dichloropropane oxidation over LaMnO3 perovskite: An experimental and DFT study. Journal of Hazardous Materials 2021, 402, https://doi.org/10.1016/j.jhazmat.2020.123473.

32. Yousefi, S.; Ansari, R.; Aghdasi, P.; Mozvashi, S.M. Structural and mechanical properties characterization of arsenene nanosheets under doping effect of transition metals: A DFT study. Physica E: Low-dimensional Systems and Nanostructures 2020, 124, https://doi.org/10.1016/j.physe.2020.114349.

33. Ghashghaee, M.; Azizi, Z.; Ghambarian, M. Conductivity tuning of charged triazine and heptazine graphitic carbon nitride (g-C3N4) quantum dots via nonmetal (B, O, S, P) doping: DFT calculations. Journal of Physics and Chemistry of Solids 2020, 141, https://doi.org/10.1016/j.jpcs.2020.109422.

34. Sadi, A.; Ouamerali, O. Theoretical Study, NBO Analysis, HOMO/LUMO and First Static Hyperpolarizability for the Structural Prediction of New 1X-tri-R- $\sigma 3 \lambda 3$-Phosphacyclohexadienyl Anion Ligands Using DFT Calculations. Journal of Structural Chemistry 2020, 61, 166-181, https://doi.org/10.1134/S002247662002002X. 
35. Rahuman, M.H.; Muthu, S.; Raajaraman, B.R.; Raja, M.; Umamahesvari, H. Investigations on 2-(4Cyanophenylamino) acetic acid by FT-IR,FT-Raman, NMR and UV-Vis spectroscopy, DFT (NBO, HOMOLUMO, MEP and Fukui function) and molecular docking studies. Heliyon 2020, 6, https://doi.org/10.1016/j.heliyon.2020.e04976.

36. Jin, R.-Y.; Tang, T.; Zhou, S.; Long, X.; Guo, H.; Zhou, J.; Yan, H.; Li, Z.; Zuo, Z.-Y.; Xie, H.-L.; Tang, Y.-P. Design, synthesis, antitumor activity and theoretical calculation of novel PI3Ka inhibitors. Bioorganic Chemistry 2020, 98, https://doi.org/10.1016/j.bioorg.2020.103737.

37. Mumit, M.A.; Pal, T.K.; Alam, M.A.; Islam, M.A.-A.-A.-A.; Paul, S.; Sheikh, M.C. DFT studies on vibrational and electronic spectra, HOMO-LUMO, MEP, HOMA, NBO and molecular docking analysis of benzyl-3-N-(2,4,5-trimethoxyphenylmethylene)hydrazinecarbodithioate. Journal of Molecular Structure 2020, 1220, https://doi.org/10.1016/j.molstruc.2020.128715.

38. Siddiqui, S.A. In silico design of organic $\mathrm{p}-\mathrm{n}$ junction diodes using quantum chemical calculations. Journal of Computational Electronics 2020, 19, 80-90, https://doi.org/10.1007/s10825-020-01447-z.

39. Adejumo, T.T.; Tzouras, N.V.; Zorba, L.P.; Radanović, D.; Pevec, A.; Grubišić, S.; Mitić, D.; Anđelković, K.K.; Vougioukalakis, G.C.; Čobeljić, B.; Turel, I. Synthesis, Characterization, Catalytic Activity, and DFT Calculations of $\mathrm{Zn}(\mathrm{II}) \quad$ Hydrazone Complexes. Molecules 2020, https://doi.org/10.3390/molecules25184043.

40. Ammar, H.Y.; Eid, K.M.; Badran, H.M. Interaction and detection of formaldehyde on pristine and doped boron nitride nano-cage: DFT calculations. Materials Today Communications 2020, 25, https://doi.org/10.1016/j.mtcomm.2020.101408.

41. Yoshikawa, T.; Yoshihara, J.; Nakai, H. Large-scale excited-state calculation using dynamical polarizability evaluated by divide-and-conquer based coupled cluster linear response method. The Journal of Chemical Physics 2020, 152, https://doi.org/10.1063/1.5124909.

42. Chen, H.; Liu, M.; Yan, T. Molecular multipoles and (hyper)polarizabilities of water by ab initio calculations. Chemical Physics Letters 2020, 752, https://doi.org/10.1016/j.cplett.2020.137555.

43. Czajkowski, K.M.; Antosiewicz, T.J. Effective dipolar polarizability of amorphous arrays of size-dispersed nanoparticles. Opt. Lett. 2020, 45, 3220-3223, https://doi.org/10.1364/OL.391647.

44. Sommers, G.M.; Calegari Andrade, M.F.; Zhang, L.; Wang, H.; Car, R. Raman spectrum and polarizability of liquid water from deep neural networks. Physical Chemistry Chemical Physics 2020, 22, 10592-10602, https://doi.org/10.1039/D0CP01893G.

45. Morimoto, K.; Tsujioka, H.; Kitagawa, D.; Kobatake, S. Photoreversible Birefringence Change of Diarylethene Single Crystals as Revealed by Change in Molecular Polarizability Anisotropy. The Journal of Physical Chemistry A 2020, 124, 4732-4741, https://doi.org/10.1021/acs.jpca.0c02774" https://doi.org/10.1021/acs.jpca.0c02774.

46. El-Mansy, M.; Ismail, M. Structural, conformational, optical, and non-linear optical behavior of ethyl (6ethyl 5, 6-dihydro 4, 5-dioxo $4 \mathrm{H}$ pyrano [3, 2-c] quinolin-3yl) 2-oxoacetate (EPQOA): comparative theoretical and experimental studies. Optical Quantum Electronics 2021, 53, https://doi.org/10.1007/s11082-021-02749-7.

47. El-Mansy, M.; Osman, W.; Abdelsalam, H. The electronic and optical absorption properties of pristine, homo and hetero Bi-nanoclusters. Chemical Physics 2021, 111113, https://doi.org/10.1016/j.chemphys.2021.111113.

48. Bayoumy, A.M.; Osman, Y.O.; Elhaes, H.; Ibrahim, M.A.; El-Mansy, M.A. Effect of substitutions on the electronic properties of acetylsalicylic acid. Optical Quantum Electronics 2021, 53, https://doi.org/10.1007/s11082-020-02725-7. 